\title{
Development of a New Testing Approach for Decentralised Technical Sustainable Drainage Systems
}

\author{
Johannes Wolfgang Neupert, Philipp Lau, Daniel Venghaus and Matthias Barjenbruch *
}

check for updates

Citation: Neupert, J.W.; Lau, P.; Venghaus, D.; Barjenbruch, M. Development of a New Testing Approach for Decentralised Technical Sustainable Drainage Systems. Water 2021, 13, 722. https://doi.org/ 10.3390/w13050722

Academic Editor: Brigitte Helmreich

Received: 9 February 2021

Accepted: 3 March 2021

Published: 6 March 2021

Publisher's Note: MDPI stays neutral with regard to jurisdictional claims in published maps and institutional affiliations.

Copyright: (c) 2021 by the authors. Licensee MDPI, Basel, Switzerland. This article is an open access article distributed under the terms and conditions of the Creative Commons Attribution (CC BY) license (https:// creativecommons.org/licenses/by/ $4.0 /)$.

\author{
Chair of Urban Water Management, Technical University of Berlin, Gustav-Meyer-Allee 25, \\ 13355 Berlin, Germany; neupert@tu-berlin.de (J.W.N.); philipp.lau@tu-berlin.de (P.L.); \\ daniel.venghaus@tu-berlin.de (D.V.) \\ * Correspondence: matthias.barjenbruch@tu-berlin.de
}

\begin{abstract}
A part of the sustainable drainage systems (SuDS) are used to treat stormwater and must be tested for their hydraulic performance and the removal efficiency to assess serviceability and retention of the pollutants efficacy for in situ use. Current test procedures provide a good basis for laboratory testing SuDS on the test stand. However, the evaluation is not sufficiently representative to compare different SuDS with each other or for in situ use. The individual steps and specifications of an applied test procedure in Germany were considered and evaluation and optimizations for the test substance and sampling methodology of SuDS on the test stand were proposed. A comparison of the particle size distribution of the test substance Millisil W4 currently in use and total suspended solids of real road runoff was made, which showed that the presented test substance of real road-deposited sediments (RDS) provides a better reference for the test conditions and they could be the basis for more representative test methods. A particle size distribution was proposed for this new test substance. Furthermore, two methods of sampling were compared, which showed that a full flow sampling is preferable to a discrete sample. At the same time, it was shown that a separation limit of $20 \mu \mathrm{m}$ is sufficient for the determination of $\mathrm{TSS}_{63}$.
\end{abstract}

Keywords: sustainable drainage systems; lab-scale testing procedures; road-deposited sediments; particle size distribution; test substance

\section{Introduction}

In Germany, the legislature has ruled in the Water Resources Act (2009) $§ 55$ that precipitation water should either be discharged via a sewerage system without mixing, percolate locally or be discharged directly (in ditches) [1]. However, in order to ensure good and sustainable water protection, the road runoff of storm water sewers, an underestimate source of contamination, requires treatment [2-4]. This is usually not the case in Germany, so that road runoff is usually discharged untreated into surface waters [5]. A set of rules for the treatment of stormwater runoff for discharge into surface waters "Requirements for stormwater treatment-DWA A102" (DWA-A 102) [6] has currently been published. According to this, the stormwater of a traffic area with an annual average daily traffic $($ AADT $)>2000$ is considered to be moderately polluted and generally requires appropriate technical treatment if it is to be discharged into surface waters or groundwater [6,7]. In the federal state of North Rhine-Westphalia (NRW), the decree "Requirements for stormwater drainage in the separation process" is already being applied [8]. The basis for the categorization is the total pollution potential of the traffic area or surface pollution by pollutants, measured by the content of total suspended solids (TSS) in the road runoff. The focus is on particulate contamination, with TSS $_{63}$ as the guiding parameter, which describes the solid fraction smaller than $63 \mu \mathrm{m}$ [9]. Due to the physical and chemical properties of this fraction, it has a particularly strong tendency to adsorb pollutants [10]. However, a laboratory determination of the TSS $_{63}$ parameter is still an object of investigation, for which a detailed sample preparation must be defined [9]. 
Road-deposited sediments (RDS) are a complex mixture of materials introduced by the environment and mainly by human activity [11]. The content and composition of RDS and TSS in road runoff are strongly influenced by the boundary conditions of the catchment area and the sources of pollution. TSS originates from dust precipitation, road surface, nonexhaust emission such as brake and tyre wear, among other things [11-13]. In Germany, for example, total tyre wear from road traffic amounts to 133,000 $\mathrm{t} / \mathrm{a}$, which represents the largest source of microplastic emissions into the aquatic environment [14,15]. It should be noted, this estimate is based on mass losses of the vehicle tyre and therefore only considers the pure rubber component. However, since the wear process is an interaction between the tread of the tyre, the road surface and the particles on it, the resulting particles are called tyre and road wear particles (TRWP) [16]. Furthermore, TRWP contain other environmentally relevant components such as heavy metals (e.g., zinc oxide), soot, silica and plasticizers, which may contain polycyclic aromatic hydrocarbons (PAH) [16-18].

Decentralised and centralised sustainable drainage system (SuDS) are mentioned in the Code of Practice DWA-A 102 [6] as measures for the removal of TRWP. These are attributed to the technical SuDS, which operating principle is based on sedimentation and filtration or chemical processes. Another category is represented by "green" SuDS, whereby the removal of pollutants is mainly performed by their soil media and vegetation [19]. This paper will focus on the technical SuDS.

Should the Code of Practice DWA-A 102 be applied in legislation, there will be a compulsion to act for those subjects to disposal obligations and the demand for the applications of SuDS will increase.

\section{Test Procedures for SuDS}

Only a few countries have developed test procedures for decentralised technical SuDS (e.g., Austria [20], UK [21], USA [22], Netherlands [23], Germany [24,25], Switzerland [26]) $[7,19]$. All mentioned countries have in common, the testing of SuDS for TSS retention. The test procedures applied in Germany are given on the one hand by the regulations in North Rhine-Westphalia for discharges into surface waters and on the other hand by the approval principles of the German Institute for Construction Technology (DIBt) for discharges into groundwater, but both are not applied uniformly throughout Germany $[7,19]$. The determination of the TSS retention of the regulation in North RhineWestphalia is based on the DIBt test protocol [25]. It lacks in Germany a uniform testing procedure for SuDS for introduction into surface waters. [13]. The DIBt test protocol investigates and validates SuDS for hydraulic performance, TSS retention and remobilisation, removal of total petroleum hydrocarbons, removal of dissolved heavy metal removal and their remobilisation due to de-icing salt conditions [7,24]. In Addition, the DIBt also specifies the structural conditions of a SuDS, so that, for example, $100 \%$ treatment of the road runoff is required and no bypass is permitted [24].

Laboratory tests are indispensable in the research and development of such systems, since in situ tests are only partially possible and very costly. Another objective of a test is reproducibility, in order to be able to compare different SuDS, and representativeness, in order to be able to assess the efficiency in situ [9].

The boundary conditions and test parameters for the DIBt test protocol were developed by Schmitt (2010) [9]. To validate the retention of TSS, a test substance was sought that would represent pollutants such as PAH and particulate heavy metals as substitute parameters. The premise was to find a reproducible constant particle size distribution (PSD) of a substance available on the market [9]. The silica sand material Millisil W4 (Quarzwerke GmbH, Weferlingen (Germany)) was selected, which is a rock flour with a particle density of $2.65 \mathrm{~g} / \mathrm{cm}^{3}$ and is used as a concrete aggregate [9].

Millisil W4 provides the DIBt test protocol with the basis for reproducibility, but only insufficient representativeness. In long-term in situ test series with event-driven automatic samplers, decentralised SuDS were investigated in an urban road and also in the laboratory using the DIBt test protocol $[27,28]$. A comparison of the results shows that no system 
achieved the TSS retention determined in the laboratory in situ, which is also justified by the in situ test conditions (Table 1).

Table 1. Test stand and in situ results of decentralized filter systems results of the DSWT research Project [28].

\begin{tabular}{|c|c|c|c|c|c|c|}
\hline Removal [\%] & & Storm Drain & $\begin{array}{c}\text { Storm Drain + } \\
\text { Leaf Basket }\end{array}$ & System A & System B & System C \\
\hline $\begin{array}{l}\text { TU Berlin test stand } \\
\text { Millisil W4 } \\
\text { (according to DIBt) }\end{array}$ & mean & 49 & 57 & 72 & 61 & 63 \\
\hline $\mathrm{n}$ & & (3) & (5) & (5) & (7) & (7) \\
\hline TSS Removal/in situ ${ }^{1}$ & $\begin{array}{l}\text { Median } \\
\text { mean }\end{array}$ & $\begin{array}{l}39 \\
39\end{array}$ & $\begin{array}{l}57 \\
44\end{array}$ & $\begin{array}{l}48 \\
49\end{array}$ & $\begin{array}{l}48 \\
41\end{array}$ & $\begin{array}{l}35 \\
40\end{array}$ \\
\hline $\mathrm{TSS}_{63} \mathrm{removal} /$ in situ $^{1}$ & $\begin{array}{l}\text { Median } \\
\text { mean }\end{array}$ & $\begin{array}{l}33 \\
33\end{array}$ & $\begin{array}{l}46 \\
44\end{array}$ & $\begin{array}{l}56 \\
52\end{array}$ & $\begin{array}{l}49 \\
24\end{array}$ & $\begin{array}{l}36 \\
23\end{array}$ \\
\hline
\end{tabular}

${ }^{1}$ in situ sampling boundary: e.g., min. sampled road runoff $0.3 \mathrm{~L} / \mathrm{s}$.

The compared systems are based on the operating principles of sedimentation (System A) and sedimentation and filtration (System B and System C). According to the manufacturer's specifications, System B and System C can also be used for the retention of dissolved heavy metals. System B is designed for retrofitting, the other two systems can only be installed with construction work [28]. As a reference, the road gully without SuDS was also tested.

To improve the representativeness of the laboratory test and thus reduce the differences between the in situ and laboratory results, one approach is to consider the choice of test substance. In the opinion of the State Office for Nature, Environment and Consumer Protection (LANUV), the retention efficiency could be determined not only by the test substance Millisil W4. [29]. Therefore, an alternative test substance will be developed and tested in this paper. The development of a representative test protocol as well as the precise investigation of RDS is a very complex procedure. Nevertheless, the aim is to bring both together.

The use of real fractionated RDS will be examined as an alternative novel test substance. The developed method for the investigation of RDS is presented, which is also the basis for the preparation of the test substance. Furthermore, real road runoff will be investigated in order to compare the results of the RDS investigation. Moreover, the scope also includes the evaluation of the sampling and the analytical method of the test protocol. From the knowledge gained, it is possible to design and evaluate a representative test substance.

\section{Material and Methods}

\subsection{RDS Field Study}

The solid retention of a SuDS depends on the particle characteristics, such as size, density, solubility and shape [30]. The properties of the road runoff water itself, such as temperature or dissolved de-icing salt, have only a negligible effect [31]. The choice of the test substance Millisil W4 is argued in Schmitt (2010) with a PSD comparison [9]. In this respect, the question of which particle size fractions are relevant for discharge and how the PAH and heavy metal loads are distributed among the PSD was investigated. In this regard, average PSD for RDS [32-36], heavy metals [32,37] and PAHs [32,38] were compiled based on literature (Figure 1). Furthermore, road sweeping results are in Figure 1 presented by Gelhardt (2017) [30], who carried out investigations into the representativeness of Millisil W4 with RDS. Since the reduction in microplastic emissions is currently becoming increasingly important, the PSD of TRWP is also considered in Figure 1 [39]. 


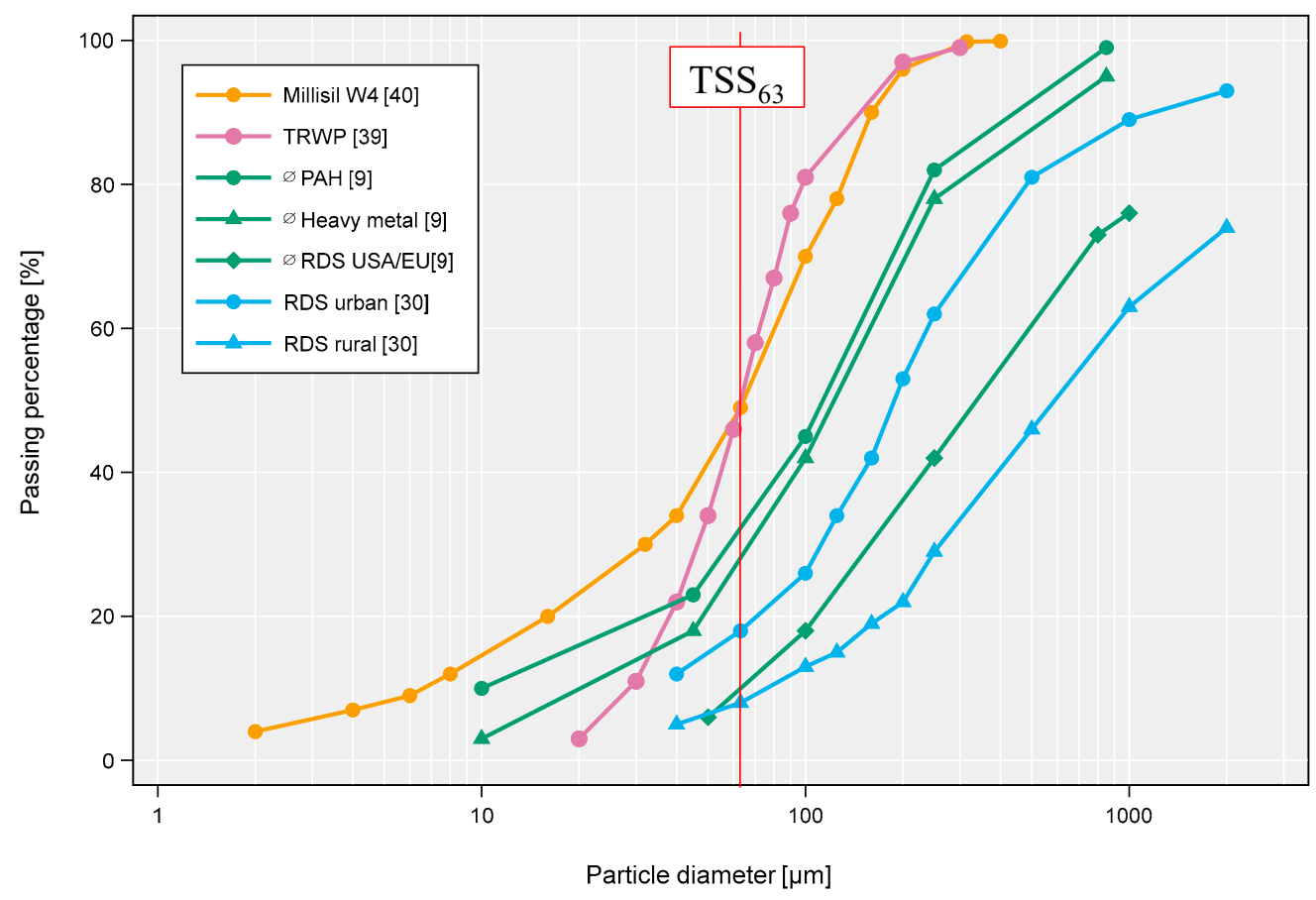

Figure 1. Particle size distributions of Millisil W4 [40], tyre and road wear particles (TRWP) [39], polycyclic aromatic hydrocarbons (PAH) [9], heavy metal [9] and road-deposited sediments (RDS) [9,30].

In terms of particle size and the TSS $_{63}$ parameter, Millisil W4 is close to TRWP and represents over $80 \%$ of the fractions for PAHs and heavy metals. It also shows that retention of $\mathrm{TSS}_{63}$ alone is not sufficient to improve water quality, but that fractions $>63 \mu \mathrm{m}$ are also relevant.

Although Gelhardt (2017) [30] was able to show a comparable settling rate of Millisil W4 with a real RDS particle composition, nevertheless, through interactions in the overall matrix, the real behaviour is not sufficiently reproduced, which contributes to the differences between the in situ and laboratory results [29,41].

In the context of this work, RDS will be investigated for a representative PSD. For this purpose, road sweepings were sampled and analysed at various locations in Berlin throughout the year.

The aim is to collect a general statistical average of the PSD of RDS. It is not the scope of the work to investigate or evaluate the RDS samples for the different environmental and seasonal influences. This would require a much more detailed consideration of the influencing parameters, such as the actual speeds and volumes of traffic, weather conditions (dry periods, humidity), roughness of the road surface, surrounding vegetation, road cleaning, etc.

As shown in Table 2, diverse locations were chosen to represent as many different types of urban topography as possible Initially, $40 \mathrm{~m}^{2}$ (position A) were sampled, but then it turned out that aliquot sampling has the similar distribution. It is more important where the sample is taken on the roadway. Therefore, an area of $1.5 \mathrm{~m}$ along the kerb and $0.8 \mathrm{~m}$ towards the road centre was chosen (position B-I).

Table 2. Road sweeping field study/catchent loactions, sampling months, maximum permitted speed ( $v_{\max }$ ) and annual average daily traffic (AADT).

\begin{tabular}{|c|c|c|c|c|c|c|c|c|c|}
\hline Location & $\begin{array}{c}\text { Straight Road } \\
\text { A }\end{array}$ & $\begin{array}{c}\text { Straight Road } \\
\text { B }\end{array}$ & $\begin{array}{c}\text { Traffic Light } \\
\text { C }\end{array}$ & $\begin{array}{c}\text { Curve } \\
\text { D }\end{array}$ & $\begin{array}{c}\text { Gradient } \\
\text { E }\end{array}$ & $\begin{array}{c}\text { Motorway } \\
\text { Slip Road } \\
\text { F }\end{array}$ & $\begin{array}{c}\text { Round-About } \\
\text { G }\end{array}$ & $\begin{array}{c}\text { Resident Area } \\
\text { H }\end{array}$ & $\begin{array}{c}\text { Bus Loop }{ }^{2} \\
\text { I }\end{array}$ \\
\hline Month & $3 / 4 / 5 / 6 / 7 / 8 / 9$ & $2 / 7 / 8 / 9$ & $2 / 7 / 7 / 8 / 9$ & $2 / 7 / 8 / 9$ & $2 / 7 / 8 / 9$ & $2 / 7 / 8 / 9$ & $2 / 7 / 8 / 9$ & $2 / 7 / 8 / 9$ & $2 / 8 / 9$ \\
\hline n & 7 & 4 & 5 & 4 & 4 & 4 & 4 & 4 & 3 \\
\hline $\mathbf{v}_{\max }[\mathbf{k m} / \mathbf{h}]$ & 50 & 50 & 50 & 50 & 50 & 70 & 50 & 30 & 50 \\
\hline $\mathrm{AADT}^{1}$ & 29,600 & 9362 & 12,780 & 9362 & 8949 & 48,510 & 8460 & 11,430 & 8910 \\
\hline
\end{tabular}


RDS are not homogeneously distributed on the road surface. According to Sieker and Grottker [43], in the area $2.2 \mathrm{~m}$ from the kerbstone $>90 \%$ of the total RDS of roads with kerbs (i.e., mainly in urban areas) is located [43]. This means that for a representative RDS sample, it is not necessary to investigate the entire road, but it is sufficient to look at the side area. In order to confirm this insight, a three-lane road in Berlin was divided into 8 areas and sampled.

The RDS Samples are collected with a hand brush and dustpan (Figure 2a), as has been done by many authors in RDS studies [44-46]. For this method, depending on the pavement surface, a recovery rate of $97 \%$ for concrete and $91 \%$ for asphalt was determined. The main prerequisite for possible sampling is a dry road surface. Even slight moisture causes the particles to adhere to the broom and does not allow representative samples to be taken. The broom must be carefully cleaned off before sampling with the broom begins. Special attention must be paid to depression where the pavement meets the kerb because particles are difficult to retrieve from these areas. The sample is then transferred from the dustpan into the sample container using a funnel and brush. Figure $2 b$ shows a before/after close-up of a sampling.

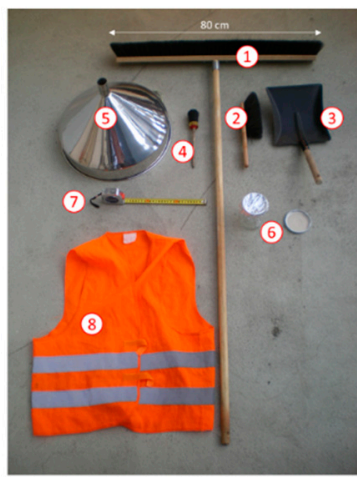

(a)

\section{1: brooms \\ 2: hand brushes \\ 3: dustpan \\ 4: brushes \\ 5: funnel \\ 6: sample \\ 7: container \\ 8: measuring tape \\ 9: safety waistcoat}

Figure 2. (a) RDS sample equipment (b) before/after close-up of a RDS sampling.

The RSD are then fractionated by a sieve analysis according to DIN 66165. The standard specifies two ways of sieving: dry and wet sieving [47]. With wet sieving and subsequent drying, there is a risk of changing the particle properties with regard to the material properties and agglomeration behaviour. As the RDS are not only analysed but also serve as test substance, dry sieving is therefore primarily suitable. According to DIN 66165 , wet sieving is suitable for particles smaller than $20 \mu \mathrm{m}$, but since the material is not suitable as test substance after wet sieving, the smallest fraction 0-63 $\mu \mathrm{m}$ is not further subdivided [47].

The test material composition is divided into six fractions: $2000-1000 \mu \mathrm{m} / 1000$ $500 \mu \mathrm{m} / 500-250 \mu \mathrm{m} / 250-125 \mu \mathrm{m} / 125-63 \mu \mathrm{m}$ and 63-0 $\mu \mathrm{m}$. The RDS samples are placed on the top sieve of the sieve set and sieved with an analytical sieve shaker. The sieve shaker runs twice for 5 min at maximum intensity. Between the two runs, a 2 min break must be observed to allow the particles to settle [47]. The fractions are then weighed in the laboratory and a grading curve is plotted.

\subsection{Road Runoff Study}

To determine the RDS washed off with the stormwater into the aquatic environment via road runoff, additional samples must be taken and analysed during precipitation events. The washing-off behaviour of RDS depends on the catchment area, as well as the connection area, AADT, surface condition, interval of street cleaning, but also, in particular, with regard to an inhomogeneous distribution of the RDS on the road surface. For constructive reasons, the rainwater often accumulates in the gutter, where the RDS also accumulate to a larger amount. Accordingly, the particles are also exposed to a higher flow than only directly 
through precipitation [43]. There are several methods of investigating the washing-off behaviour that thus describe the entry into the road runoff. These include, for example, observations of the solids loading of the road surface before and after real rain events [48], wash-off experiments with simulated precipitation [49], computer-aided modelling [50] or direct sampling of the road runoff [28,51-53].

The latter is usually implemented by partial flow sampling, which, however, can have a high error rate in relation to TSS determination and the uncertainties are unknown [28]. Due to the heterogeneous distribution of the solids in the entire water phase, errors occur, which are, however, avoided by full flow sampling [28]. For this reason, a sampling basket (SB) was developed within the RAU research project, which can be placed into a gully pot (Figure 3) [54]. The SB basically consists of a stack of sieves having mesh sizes to any microns, technically down to a separation limit of $10 \mu \mathrm{m}$. However, for the investigations carried out, a separation limit of $20 \mu \mathrm{m}$ is used. It can be assumed that finer particles can also be separated within the framework of filter cake formation. This is particularly relevant with regard to the guiding parameter $\mathrm{TSS}_{63}$.

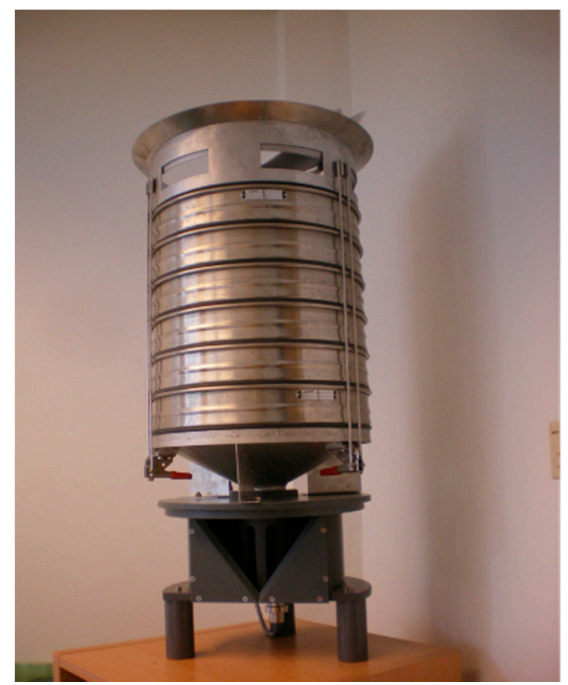

(a)

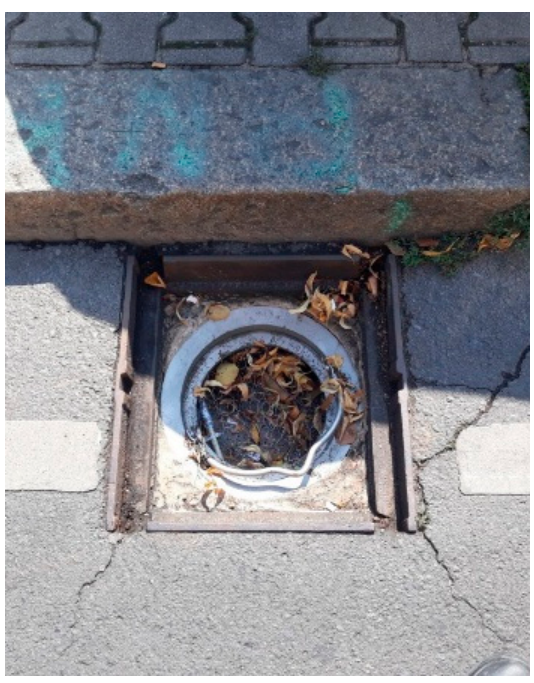

(b)

Figure 3. (a) Road runoff sampling basket (full flow sampling) and (b) in situ use.

For the road runoff sampling, an intersection area in Berlin with AADT of 10,000-30,000 was chosen [42]. The SB is inserted into the gully pots in dry weather and recovered after a single rain event. The rain data were provided by the local weather service. The samples were then fractionated and analysed using the wet sieving method, as explained in the next section. Two SB were used in relation to the studies presented here, so that two gully pots of the intersection area could be sampled simultaneously. A total of three rain events could be captured, so that six samples could be collected.

\subsection{Sampling Methodology for the Evaluation of SuDS on the Test Stand}

The investigations on the test stand are presented in the following. The test stand of the Department of Urban Water Management at the TU of Berlin meets the requirements of the "DIBt Approval Principle for Precipitation Water Treatment Plants Part 1: Plants for the connection of motor vehicle traffic areas up to $2000 \mathrm{~m}^{2}$ and treatment of the wastewater for subsequent infiltration into the soil and groundwater" [24].

The test stand consists of a feed tank $\left(10 \mathrm{~m}^{3}\right)$, a centrifugal pump, two measuring sections, each with a magnetic flow meter (MFM) and electrical control valve, a dosing station, a static mixer, a road gully (with a decentralised technical SuDS) and an intermediate tank for the discharge. The measuring sections consist of a main line in DN 100 for conveying the flows of $3 \mathrm{~L} / \mathrm{s}$ to $16 \mathrm{~L} / \mathrm{s}$ and a secondary line in DN 25 for conveying the 
flows $<3 \mathrm{~L} / \mathrm{s}$. The Set up can therefore simulate any precipitation dynamics of connecting surfaces from $250 \mathrm{~m}^{2}$ to $1000 \mathrm{~m}^{2}$. The flow rate at the test stand is regulated by an MFM and a software-controlled valve (Figure 4).

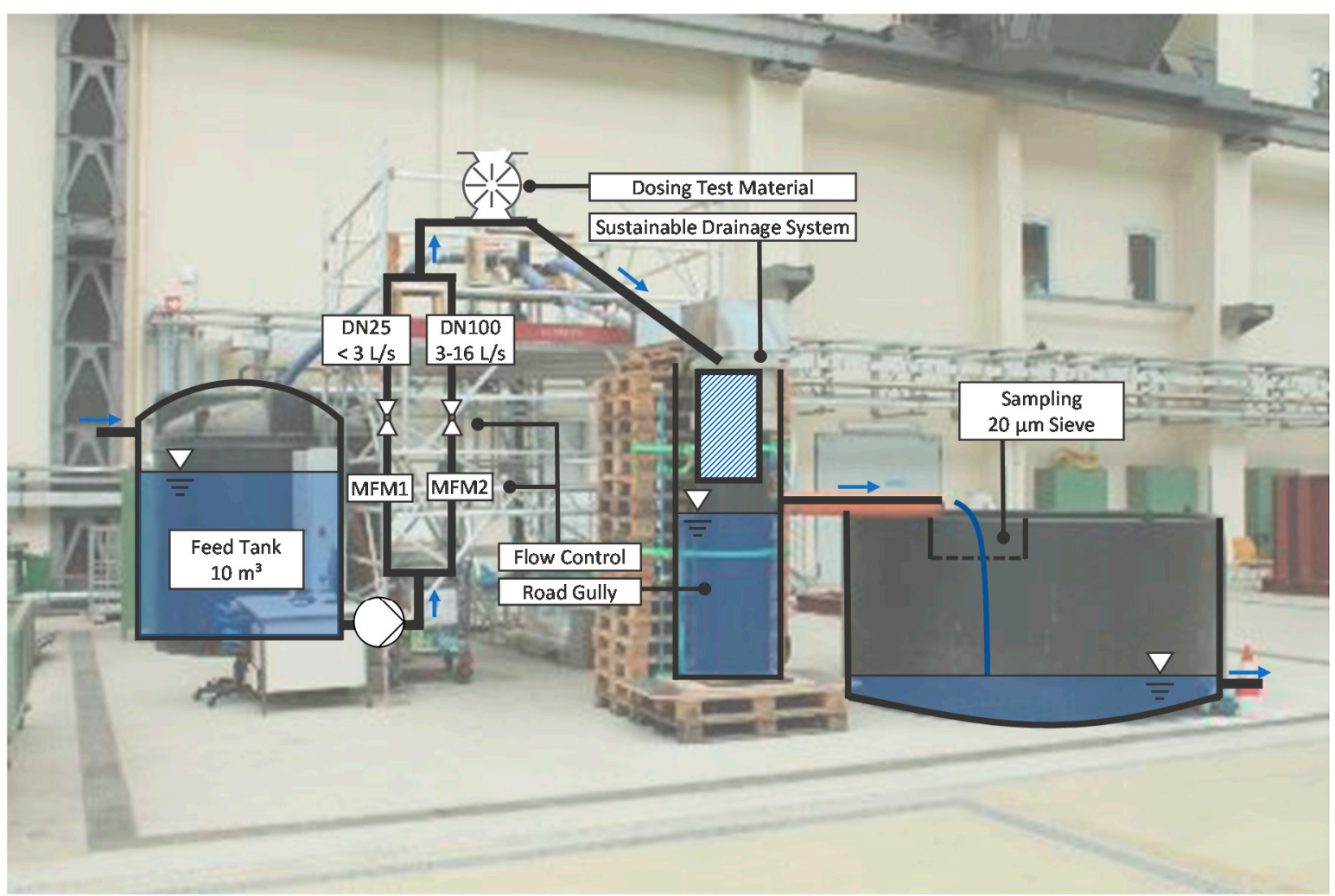

Figure 4. Test stand of the Department of Urban Water Management at the TU of Berlin according to DIBt requirements.

Millisil W4 is added by means of a twin-screw feeder. The quantity added is controlled by the motor speed of the twin screw feeder and is adjusted in advance according to the specifications. A variation in dosage of up to $0.76 \%$ was observed and is neglected in the following. The advantage of this process is the precisely adjustable dosing and continuous feeding without intervals. However, the unit is only suitable for fine-grained materials and not for road sweepings (particles $>0.5 \mathrm{~mm}$ ). Therefore, a rotary valve is used for the addition of road sweepings. The bulk material is fed into the chambers via an inlet area by gravity. Due to rotation, the material contained in the cells is transported in the direction of the outlet. The conveying capacity is determined by the speed of the cellular wheel and by the predefined size of the chambers, which has been specially made for the test procedure. In the outlet area, the dosed bulk material falls into the inlet flow due to gravity. The rotary valve, unlike a vibratory conveyor otherwise used, works vibration-free and thus prevents segregation of the test substance.

In the DIBt test protocol, discrete samples by scooping are provided at the outlet at specified times to assess the TSS retention. The TSS is determined according to DIN 38409-2 with a separation limit of $0.45 \mu \mathrm{m}$ [55]. An alternative method for discrete sampling is the continuous sampling of the full flow, whereby the entire outlet volume flow is passed through a stainless steel sieve (full flow sampling). Which is the appropriate method for the test procedure with RDS shall be decided by determining the recovery. For this purpose, a constant volume flow of $0.5 \mathrm{l} / \mathrm{s}$ is set on the test stand for $30 \mathrm{~min}$ and a constant volume flow of $277 \mathrm{mg} / 1 \mathrm{RDS}$ is constantly dosed (250 $\mathrm{g}$ in total). The qualified random samples are taken by hand according to DIN 38,402 [56]. Each qualified sample consists of 5 individual samples with a volume of $400 \mathrm{~mL}$, which were taken a total of 5 times at an interval of $5 \mathrm{~min}$. The volume of each qualified sample is therefore 2 litres. For each qualified random sample, the TSS determination is carried out three times, each time through a dried and 
balanced filter with a pore size of $0.45 \mu \mathrm{m}$. The filter with residue is then dried in a drying oven at $105{ }^{\circ} \mathrm{C}$ and balanced again. The TSS concentration can then be deduced from the two mass values and the sample volume. The same procedure is used for the full flow sampling. Since the hydraulic flow rate must be guaranteed without interruption, a lower separation limit of $20 \mu \mathrm{m}$ is selected. The mass balance is determined gravimetrically after the sieve residue has been washed back into a weighed beaker and dried until the mass is constant.

In the test procedure, a fractional analysis of the sample can be carried out in a complete flow sampling. For process-related reasons, dry sieving (input) and wet sieving (output) are compared. The effects on the respective fractions for the test material RDS are to be examined. The assessment of the retention capacity of a SuDS results from the added test substance mass minus the determined discharge in relation to the input.

Formula: Calculation of the retention efficiency (1)

$$
\eta=\left(1-\frac{\mathrm{m}_{\text {output }}}{\mathrm{m}_{\text {input }}}\right) \times 100
$$

According to ISO 11352, the determination of the recovery rate of TSS of discrete and full flow sampling is repeated eight times [57]. The same applies to the comparison of dry and wet sieving.

\section{Results and Discussion}

In the following section, the RDS results are presented, first the distribution of the particles on the road surface and then the field study on the PSD. Subsequently, the investigations of the real road runoff are shown and compared with the RDS results. Finally, the validation of the sampling methodology for the evaluation of SuDS on the test stand is presented

\subsection{RDS Field Study}

Figure 5 shows the results of the PSD of the RDS across the road surface. RDS are not homogeneously distributed on the road surface. On the middle of the road (area 5) almost no particles are detectable, which corresponds to the results of Sieker und Grottker [43]. The majority of the particles are found in the area near the kerb (area 1). Apparently, the particles are repeatedly stirred up by the traffic until they are deposited on the side area.

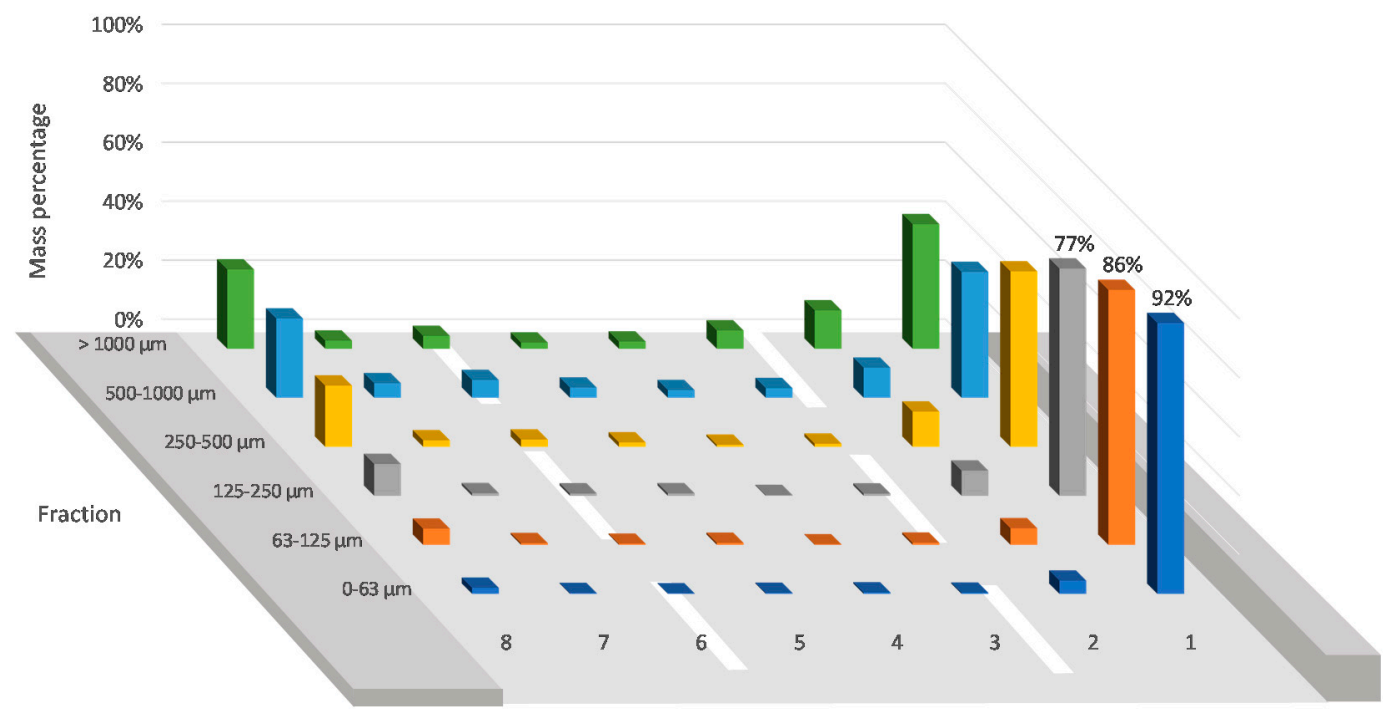

Figure 5. Particle size distribution across a road. Total width: $11.8 \mathrm{~m}$ (area 1: 0.8 m; area 2-7: 1.6 m; area 8: $1.4 \mathrm{~m}$ ). 
The small increase in area 8 is explained by a natural barrier of the slightly raised central reservation. For representative investigations, it is therefore sufficient to sample only the lateral roadway area at the kerb (area 1).

The aim is to propose a method for determining a generally applicable PSD to create a test substance made of real RSD. Figure 6 shows the average of 39 RDS particle distribution from the data in Figure 1 in comparison to the literature. The fraction $<63 \mu \mathrm{m}$ varies between $<1 \%$ and $13 \%$. The total RDS mass load ranged from $8.78 \mathrm{~g} / \mathrm{m}^{2}$ to $411 \mathrm{~g} / \mathrm{m}^{2}$, with a mean value of $63 \mathrm{~g} / \mathrm{m}^{2}$. For a uniform comparison with the literature and to reduce the influence of very coarse particles (e.g., litter), all RDS graphs are normalised to $1 \mathrm{~mm}$. This means that $1 \mathrm{~mm}$ corresponds to $100 \%$ and larger particles are not considered.

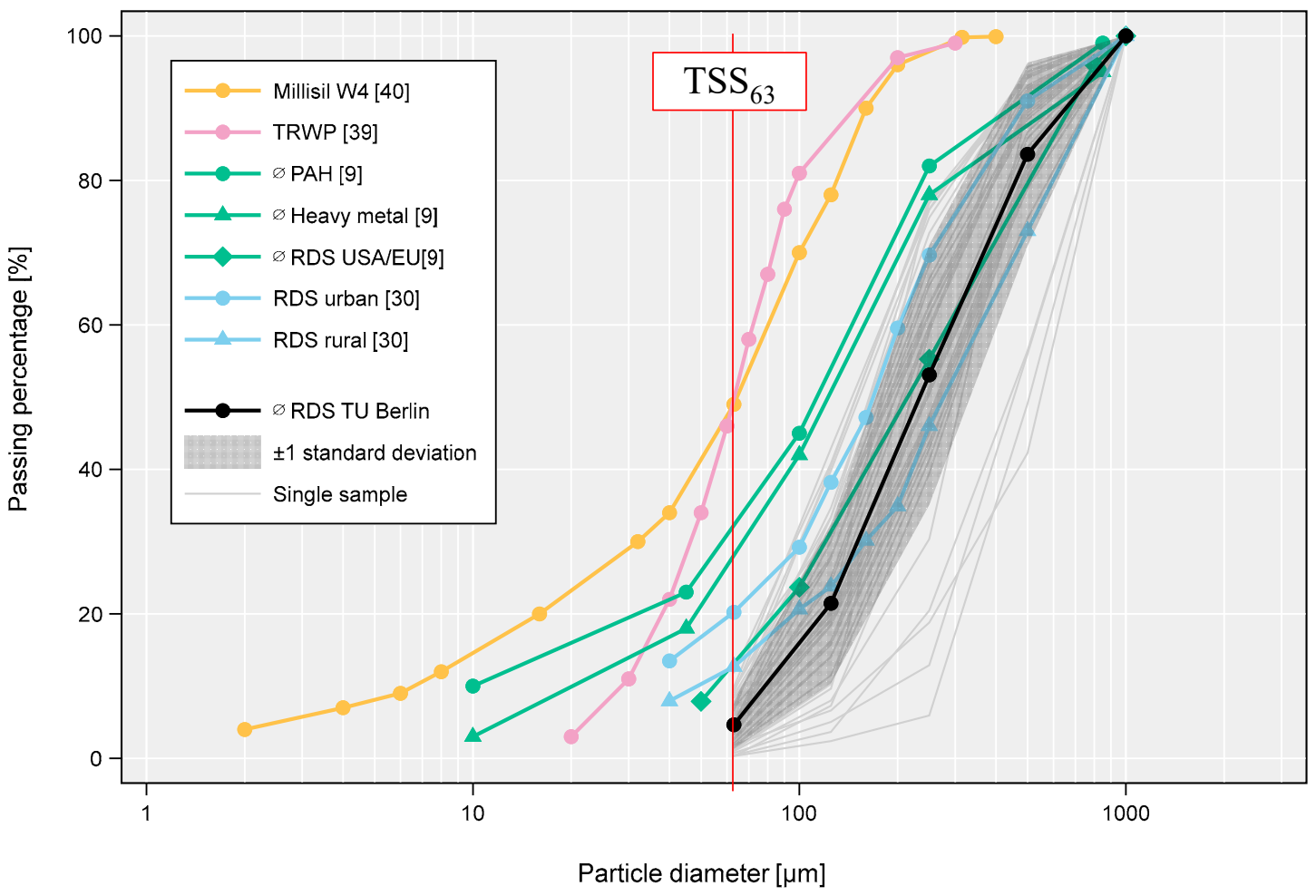

Figure 6. The RSD ( $\mathrm{n}=39$ ) in comparison to Millisil W4 [40], tyre and road wear particles (TRWP) [39], polycyclic aromatic hydrocarbons (PAH) [9], heavy metal [9] and road-deposited sediments (RDS) [9,30]. RDS graphs are normalised to 1 mm and larger particles are not considered.

As the parameters such as actual speed, actual traffic, detailed weather conditions, roughness of the road surface, etc. were or could not be recorded, it is not possible to make a statement on the influences on PSD and was not the aim of this study. A comparison with the literature in Figure 6 shows that the results of the RDS field study are in the same order of magnitude as those of Gelhardt [30] and Schmitt [9]. However, the RDS is much coarser in comparison to Millisil W4. Thus, 95\% of Millisil W4 passing $200 \mu \mathrm{m}$, covers only $40 \%$ of RDS.

The sampling basket was used to sample three different "road runoff events", with samples obtained in all fractions (Figure 7). For comparison, the PSD of Millisil W4 and TRWP is also shown in Figure 7.

The three rainfall events were sampled in the spring at two gully pots each. The total amount of precipitation (and duration) was $4.4 \mathrm{~mm}(6 \mathrm{~h}) / 5.9 \mathrm{~mm}(10 \mathrm{~h}) / 6.7 \mathrm{~mm}(7 \mathrm{~h})$. The collected mass per gully pot was $47-152 \mathrm{~g}$. The PSD of the road runoff is comparable to the PSD of the RDS and becomes slightly finer. The investigations show that the particles of the fine and coarser fractions deposited on the road are washed into the road runoff. For more precise statements, more parameters would have to be included, such as road runoff volume. Nevertheless, it is clear that the majority of the rinsed particles $(\sim 45 \%)$ are 
between $125 \mu \mathrm{m}$ and $500 \mu \mathrm{m}$. Millisil W4 covers of that range only about 20\%. Overall, Millisil W4 has a much higher proportion of fine fractions, which is why the grading curves differ widely and only represent $60 \%$ of the total road runoff.

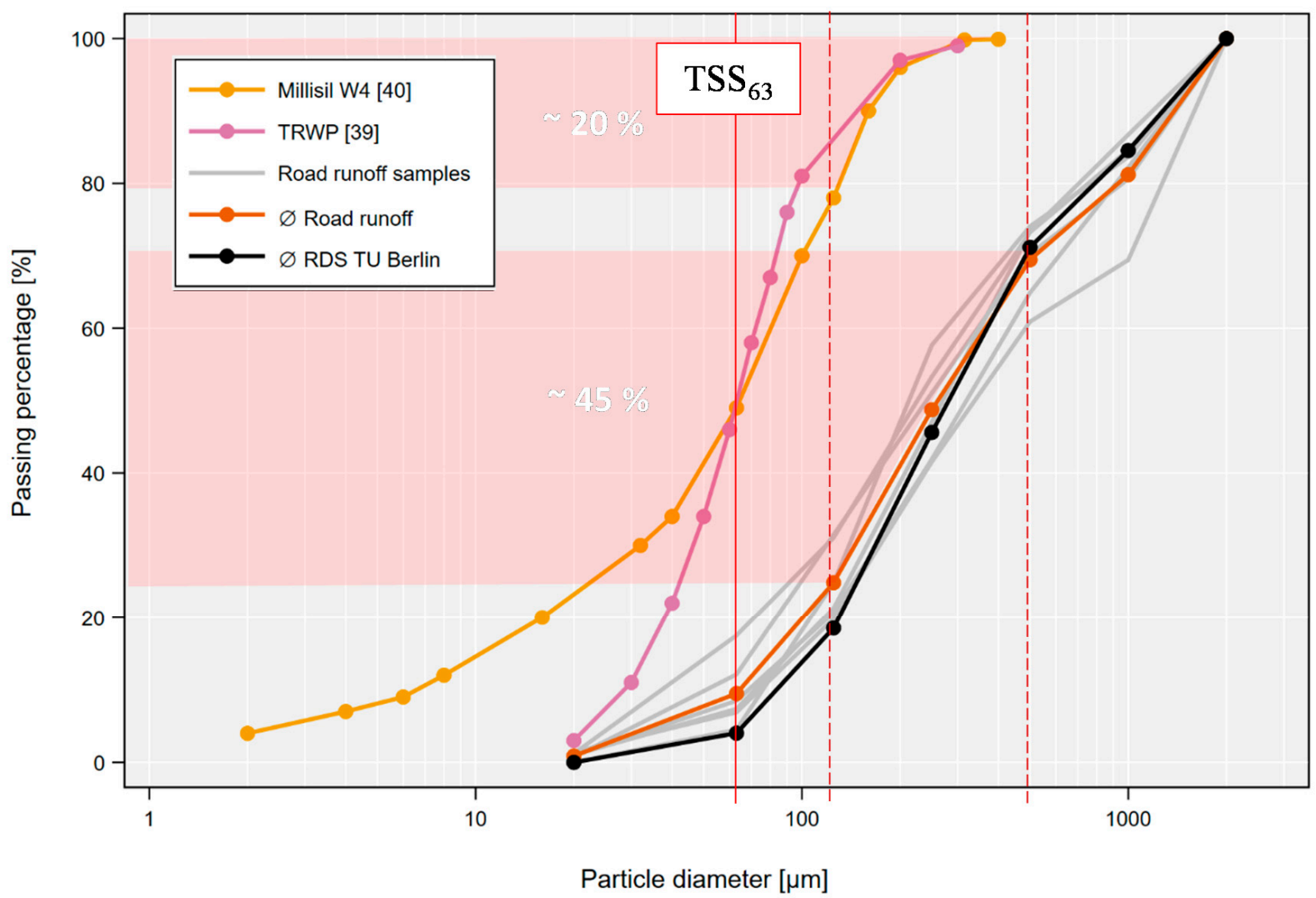

Figure 7. Road runoff PSD ( $\mathrm{n}=6)$ in compare to RSD, Millisil W4 [40], tyre and road wear particles (TRWP) [39].

If, with regard to DWA-A 102, the retention of parameter TSS $_{63}$ of a SuDS is to be evaluated more precisely, the fraction $<63 \mu \mathrm{m}$ could be enriched. Nevertheless, it is clear that the consideration of $>63 \mu \mathrm{m}$ is also relevant for the evaluation of a SuDS. This is because the majority of the load is $>63 \mu \mathrm{m}$ and potentially contributes to the reduction in the retention performance.

\subsection{Sampling Methodology for the Evaluation of SuDS on the Test Stand}

Figure 8a shows the recovery rates for the discrete sampling and full flow sampling methods. As expected, the recovery rate of $95 \%$ for full flow sampling is significantly higher than for discrete sampling $(26 \%)$. In addition to the accuracy, the precision (standard error) is also improved by a factor of 10 .

A disadvantage of the complete flow sampling compared to the discrete sampling is that the separation limit of $0.45 \mu \mathrm{m}$ cannot be realised. Therefore, it was investigated to see how far the loss caused by the separation limit of $20 \mu \mathrm{m}$ was relevant for the significance of the parameter $\mathrm{TSS}_{63}$. Furthermore, the recovery of the $\mathrm{TSS}_{63}$ fraction with $10 \mu \mathrm{m}$ and $20 \mu \mathrm{m}$ sieves was determined (Figure 8b). Processed road sweep samples $<63 \mu \mathrm{m}$ were divided into the fractions $63-20 \mu \mathrm{m}$ and $20-10 \mu \mathrm{m}$ by wet sieving. As shown in Figure $8 \mathrm{~b}$, a lower separation limit of $20 \mu \mathrm{m}$ is sufficient for the determination $(84 \%)$ of the TSS $_{63}$ for RDS. 


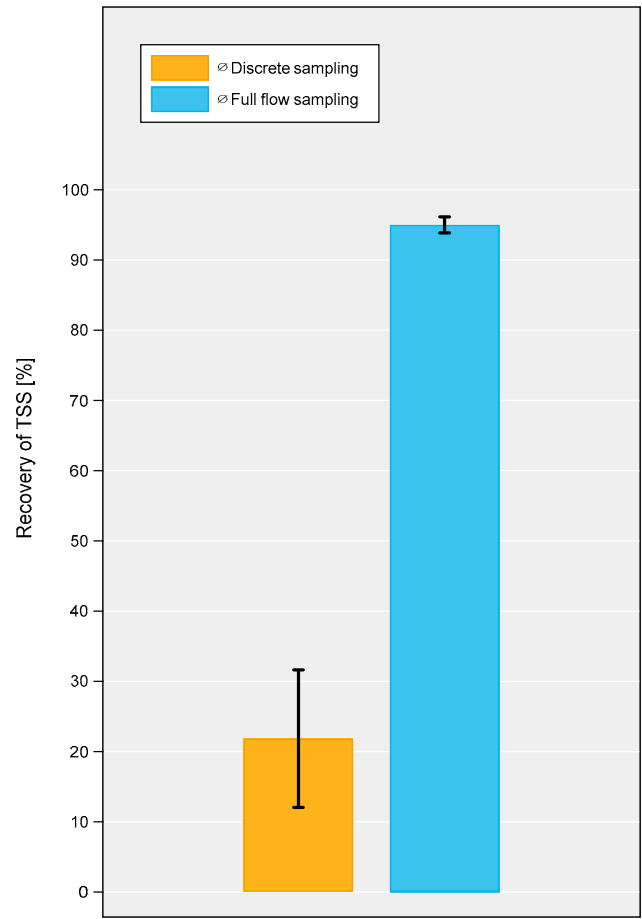

(a)

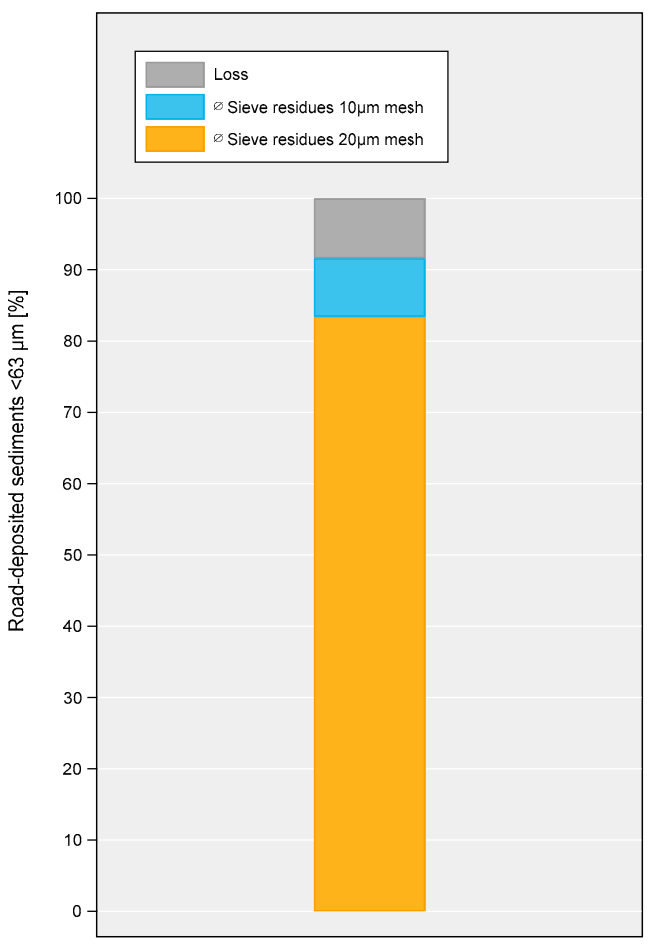

(b)

Figure 8. (a) Recovery of discrete sampling and full flow sampling $(n=8)(b)$ Road-deposited sediments $(R D S)<63 \mu m(n=8)$.

The RDS are processed as individual fractions by dry screening. For a fractional analysis of the rinsed test material, dry sieving (input) and wet sieving (output) of the test material RDS are compared for process-technical reasons. Both methods were used for the same road sweep samples, which were pre-sieved to $<1 \mathrm{~mm}$. With wet sieving, the PSD shifts slightly into the finer range (Figure 9), presumably due to the mobilisation of finer particles by the rinsing process. Both methods yield comparable results and can be used as a reliable basis for a fractional analysis of the results.

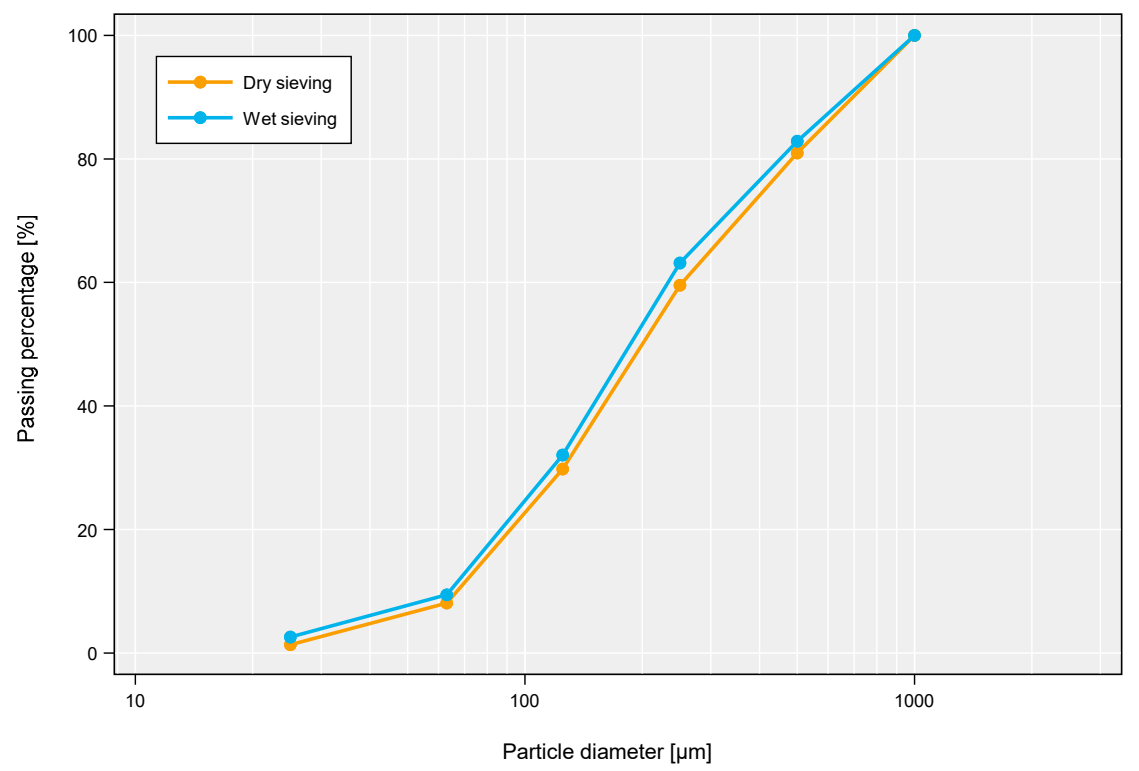

Figure 9. Comparison of wet and dry sieving of $\operatorname{RDS}(n=8)$. 


\section{Conclusions}

The DIBt test procedure provides a good basis for testing SuDS on the test stand. However, the evaluation is not sufficiently representative to make a comparison for in situ use. The individual steps and specifications of the DIBt were considered and optimisations for the test substance and sampling methodology suggested.

It could be shown that Millisil W4 represents only about $60 \%$ of the washed-off size fractions of road runoff. Thus, the test substance RDS presented represents a better reference for real conditions and provides the basis for more representative test methods. This is because the evaluation of a SuDS should not only focus on the fine fractions but should also take the entire PSD into account. In an ideal case, estimates of the economically relevant maintenance intervals and service life could thus also be created.

A PSD was proposed for the test material based on RDS samples. Nevertheless, the PSD can be adapted arbitrarily and reproducibly with the presented method and thus represent possible site-specific requirements. If the retention of the parameter TSS $_{63}$ of a SuDS is to be evaluated more precisely, the fraction $<63 \mu \mathrm{m}$ can optionally be enriched or an additional test can be performed only with the RDS $<63 \mu \mathrm{m}$ to determine the retention of $\mathrm{TSS}_{63}$.

Furthermore, two methods of sampling for the evaluation of SuDS at the test stand were compared, which showed that a complete flow sampling is preferable to a discrete sample. At the same time, it was shown that a separation limit of $20 \mu \mathrm{m}$ was sufficient for determining $\mathrm{TSS}_{63}$ and $84 \%$ of the $\mathrm{TSS}_{63}$ mass was recovered.

If it is assumed that climate change will cause increasing extreme weather events, this will pose new challenges for urban development. It is to be expected that heavy precipitation will become more intense and more frequent than is already the case today. This can result in immense damage to infrastructure and buildings, environmental damage and even danger to people [58]. Therefore, that it becomes a technically ever greater challenge to record and treat the entire road runoff materially and hydraulically. Therefore, alternative concepts such as first flush cleaning are required, in which heavily polluted storm water is treated at the beginning of a rain event. Especially in retrofit SuDS, it is doubtful that the complete road runoff can be treated due to the limited space available. According to the DIBt approval principles a bypass is not permitted.

Decentralised SuDS present a promising but cost-intensive solution to reduce the input of pollutants into the aquatic environment, but the use of end-of-pipe technology alone will not be sufficient. In order to make environmental protection more effective, it will also be necessary to combine several options for action, such as catchment-dependent measures (smart traffic control, digitally adapted municipal street cleaning) with the intelligent networking of different sub-areas.

Author Contributions: Conceptualization, J.W.N., P.L. and D.V.; methodology, J.W.N., P.L. and D.V.; software J.W.N.; validation, J.W.N. and P.L.; formal analysis, J.W.N.; investigation, J.W.N., P.L. and D.V.; resources, M.B.; data curation, J.W.N., P.L. and D.V.; writing-original draft preparation, J.W.N.; writing-review and editing, J.W.N., P.L., D.V. and M.B.; visualization, J.W.N.; supervision, M.B.; project administration, M.B.; funding acquisition, M.B. All authors have read and agreed to the published version of the manuscript.

Funding: This research was funded by BMWi- "Bundesministerium für Wirtschaft und Energie" (ZIM program), grant number FKZ16KN082023.

Institutional Review Board Statement: Not applicable.

Data Availability Statement: Data is contained within the article.

Conflicts of Interest: The authors declare no conflict of interest. The funders had no role in the design of the study; in the collection, analyses, or interpretation of data; in the writing of the manuscript, or in the decision to publish the results. 


\section{References}

1. WHG (Wasserhaushaltsgesetz). Gesetz zur Neuregelung des Wasserrechts vom 31 Juli 2009. Bundesgesetzblatt Jg. 2009, $51,2585-2621$.

2. Eriksson, E.; Baun, A.; Scholes, L.; Ledin, A.; Ahlman, S.; Revitt, M.; Noutsopoulos, C.; Mikkelsen, P. Selected stormwater priority pollutants-A European perspective. Sci. Total Environ. 2007, 383, 41-51. [CrossRef]

3. McIntyre, J.; Davis, J.; Hinman, C.; Macneale, K.; Anulacion, B.; Scholz, N.; Stark, J. Soil bioretention protects juvenile salmon and their prey from the toxic impacts of urban stormwater runoff. Chemosphere 2015, 132, 213-219. [CrossRef]

4. Barbosa, A.; Hvitved-Jacobsen, T. Highway runoff and potential for removal of heavy metals in an infiltration pond in Portugal. Sci. Total Environ. 1999, 235, 151-159. [CrossRef]

5. Hillenbrand, T. Einträge von Kupfer, Zink und Blei in Gewässer und Böden; Analyse der Emissionspfade und Möglicher Emissionsminderungsmassnahmen; Research Report 20224220/02; Naturschutz und Reaktorsicherheit; Umweltbundesamt (Umweltforschungsplan des Bundesministeriums für Umwelt): Berlin, Germany, 19 May 2005.

6. DWA-A 102/BWK-A 3. Grundsätze zur Bewirtschaftung und Behandlung von Regenwetterabflüssen zur Einleitung in OberflächengewässerEntwurf (Oktober 2016); DWA (Deutsche Vereinigung für Wasserwirtschaft, Abwasser und Abfall): Hennef, Germany, 2016.

7. Lucke, T.; Nichols, P.; Shaver, E.; Lenhart, J.; Welker, A.; Huber, M. Pathways for the Evaluation of Stormwater Quality Improvement Devices-The Experience of Six Countries. CLEAN Soil Air Water 2017, 45. [CrossRef]

8. MUNLV (Ministerium für Umwelt des Landes Nordrhein-Westfalen). Anforderungen an die Niederschlagsentwässerung im Trennverfahren; Circular Decree of the Ministry for the Environment and Nature Conservation, Agriculture and Consumer Protection: North Rhine-Westphalia, Germany, 25 May 2004.

9. Schmitt, T.G.; Welker, A.; Dierschke, M.; Uhl, M.; Maus, C.; Remmler, F. Entwicklung von Prüfverfahren für Anlagen zur dezentralen Niederschlagswasserbehandlung im Trennverfahren. In Final Report to the German Federal Foundation for the Environment; Deutsche Vereinigung für Wasserwirtschaft, Abwasser und Abfall: Hennef, Germany, 2010.

10. Gunawardana, C.; Egodawatta, P.; Goonetilleke, A. Role of particle size and composition in metal adsorption by solids deposited on urban road surfaces. Environ. Pollut. 2014, 184, 44-53. [CrossRef]

11. DWA Deutsche Vereinigung für Wasserwirtschaft. Abwasser und Abfall: Umgang mit Straßenkehricht; DWA (DWA-Regelwerk, M 378): Hennef, Germany, 2008; ISBN 978-3-940173-62-1.

12. Dierschke, M. Methodischer Ansatz zur Quantifizierung von Feinpartikeln (PM63) in Niederschlagsabflüssen in Abhängigkeit von der Herkunftsfläche. Dissertation. Technischen Universität Kaiserslautern, 2014 Kaiserslautern. Available online: https: / / kluedo.ub.uni-kl.de/frontdoor/index/index/docId/3808 (accessed on 30 November 2020).

13. OECD. Non-exhaust Particulate Emissions from Road Transport. Organisation for Economic Co-Operation and Development (OECD). 2020. Available online: http:/ / www.oecd.org/contact/ (accessed on 6 March 2021).

14. Bertling, J.; Bertling, R.; Hamann, L. Kunststoffe in der Umwelt: Mikro- und Makroplastik. Ursachen, Mengen, Umweltschicksale, Wirkungen, Lösungsansätze, Empfehlungen. Kurzfassung der Konsortialstudie, Fraunhofer-Institut für Umwelt-, Sicherheits- und Energietechnik UMSICHT (hrsg.), Oberhausen, Germany. 2018. Available online: https:/ /www.umsicht.fraunhofer.de/content/ dam/umsicht/de/dokumente/publikationen/2018/kunststoffe-id-umwelt-konsortialstudie-mikroplastik.pdf (accessed on 30 November 2020).

15. Wagner, S.; Hüffer, T.; Klöckner, P.; Wehrhahn, M.; Hofmann, T.; Reemtsma, T. Tire wear particles in the aquatic environment-A review on generation, analysis, occurrence, fate and effects. Water Res. 2018, 139, 83-100. [CrossRef] [PubMed]

16. Panko, J.M.; Chu, J.; Kreider, M.L.; Unice, K.M. Measurement of airborne concentrations of tire and road wear particles in urban and rural areas of France, Japan, and the United States. Atmos. Environ. 2013, 72, 192-199. [CrossRef]

17. Schramm, E.J. Reibung von Elastomeren auf rauen Oberflächen und Beschreibung von Nassbremseigenschaften von PKW-Reifen. Ph.D. Thesis, Universität Regensburg, Regensburg, Germany, 2002. [CrossRef]

18. Leister, G. Fahrzeugräder - Fahrzeugreifen: Entwicklung - Herstellung - Anwendung; Springer: Wiesbaden, Germany, 2015.

19. Dierkes, C.; Lucke, T.; Helmreich, B. General Technical Approvals for Decentralised Sustainable Urban Drainage Systems (SUDS)-The Current Situation in Germany. Sustainability 2015, 7, 3031-3051. [CrossRef]

20. ONORM B 2506-2. Soakaways for Rain Water from Roof Gutters and Reinforced Surfaces - Part 2: Requirements Concerning the Quality of Soakaway Rain Water and Requirements of Dimensioning, Construction and Operation of Purification Facilities (Ausgabe: 2012-04-01); Komitee 120 Abwassertechnik, Austrian Standards Institute: Vienna, Austria, 2012; pp. 1-17.

21. British Water. Assessment of Manufactured Treatment Devices Designed to Treat Surface Water Runoff. Code of Practice; British Water Treatment Device Test Code of Practice Workgroup: London, UK, 2017. Available online: https://www.britishwater.co.uk/ media/download.aspx?MediaId=1197 (accessed on 30 November 2020).

22. Arvin-Colon, R.C.; French, S.; Brown, A.N.D.R. Greenwood. Framework for a National Testing and Evaluation Program Based Upon the National Stormwater Testing and Evaluation for Products and Practices (STEPP) Initiative (WERF Report INFR2R14); Water Environment Research Foundation: Alexandria, VA, USA, 2016.

23. Boogaard, F.C. Stormwater Characteristics and New Testing Methods for Certain Sustainable Urban Drainage Systems in the Netherlands Dissertation University of Delft 2015. Available online: doi.org/10.4233/uuid:d4cd80a8-41e2-49a5-8f41-f1efc1a0ef5d (accessed on 30 November 2020). 
24. DIBt. Zulassungsgrundsätze für Niederschlagswasserbehandlungsanlagen. Teil 1: Anlagen.zur Dezentralen Behandlung des Abwassers von KfzVerkehrsflächen zur anschließenden Versickerung in Boden und Grundwasser; Approval guidelines for stormwater treatment systems. Part 1: Systems for the decentralized treatment of wastewater from vehicle traffic areas for subsequent discharge into soil and groundwater); Deutsches Institut für Bautechnik - German Institute for Structual Engineering: Berlin, Germany, 2015.

25. Dezentrale Niederschlagswasserbehandlung in Trennsystemen-Umsetzung des Trennerlasses. Available online: http://www. lanuv.nrw.de/wasser/abwasser/forschung/pdf/20111125_.Gesamtbericht.pdf (accessed on 30 November 2020).

26. ASTRA. Dokumentation, Methodik zur Prufüung der Verhältnismässigkeit von Strassenabwasserbehandlungsanlagen; ASTRA 88003; Bundesamt für Strassen ASTRA: Bern, Switzerland, 2014; pp. 1-44.

27. Venghaus, D.; Lau, P.; Barjenbruch, M. Optimized Materials and Processes for the Separation of Microplastic from the Water Cycle-OEMP Final Report, with the Collaboration of TIB-Technische Informationsbibliothek Universitätsbibliothek Hannover; Technische Informationsbibliothek (TIB) and Technische Universität Berlin, Fachgebiet Siedlungswasserwirtschaft: Berlin Germany, 2018. [CrossRef]

28. Barjenbruch, M.; Heinzmann, B.; Kober, P.; Post, M.; Remy, C.; Rouault, P.; Sommer, H.; Sonnenberg, H.; Weiß, B. Dezentrale Reinigung von Straßenabflüssen; Final Report 2016; Berliner Umweltentlastungsprogramm UEPII/2: Berlin, Germany, 2016.

29. The State Agency for Nature, Environment and Consumer Protection (LANUV)/ Decentralized Stormwater Treatment. Available online: https:/ / www.lanuv.nrw.de/umwelt/wasser/abwasser/niederschlagswasser/dezentrale-systeme (accessed on 30 November 2020).

30. Gelhardt, L.; Huber, M.; Welker, A. Development of a Laboratory Method for the Comparison of Settling Processes of RoadDeposited Sediments with Artificial Test Material. Water Air Soil Pollut. 2017, 228, 467. [CrossRef]

31. Rommel, S.H.; Gelhardt, L.; Welker, A.; Helmreich, B. Settling of Road-Deposited Sediment: Influence of Particle Density, Shape, Low Temperatures, and Deicing Salt. Water 2020, 12, 3126. [CrossRef]

32. Lau, S.-L.; Stenstrom, M.K. Metals and PAHs adsorbed to street particles. Water Res. 2005, 39, 4083-4092. [CrossRef] [PubMed]

33. Shaheen, D.G. Contributions of Urban Roadway Usage to Water Pollution Environmental Protection Technology Series; 1975 Washington D.C. National Technical Information Service: Springfield, VA, USA, 1975.

34. Brunner, G.P. Straßen als Ursachen der Verschmutzung von Regenwasserabflüssen-Ein Überblick über den Stand der Forschung. In Wasserwirtschaft; Springer: Wiesbaden, Germany, 1977; Volume 67.

35. Sansalone, J.J.; Kim, J.-Y. Transport of Particulate Matter Fractions in Urban Source Area Pavement Surface Runoff. J. Environ. Qual. 2008, 37, 1883-1893. [CrossRef] [PubMed]

36. Sommer, H. Behandlung von Straßenabflüssen, Anlagen zur Behandlung und Filtration von Straßenabflüssen in Gebieten mit Trennsystem - Neuentwicklungen und Untersuchungen. Ph.D. Thesis, Universität Hannover, Hannover, Germany, 2007.

37. Kobriger, N.K.; Geinopolos, A. Sources and Migration of Highway Runoff Pollutants Volume III: Research Report; FHWA/RD-84/059 1984; US Department of Transportation: Washington, DC, USA, 1984; pp. 1-368.

38. Krein, A.; Schorer, M. Road runoff pollution by polycyclic aromatic hydrocarbons and its contribution to river sediments. Water Res. 2000, 34, 4110-4115. [CrossRef]

39. Kreider, M.L.; Panko, J.M.; McAtee, B.L.; Sweet, L.I.; Finley, B.L. Physical and chemical characterization of tire-related particles: Comparison of particles generated using different methodologies. Sci. Total Environ. 2010, 408, 652-659. [CrossRef]

40. Quarzwerke GmbH. Stoffdaten MILLISIL®-Mehle Werk Weferlingen; Material Data MILLISIL®-flours Plant, 2015 Weferlingen. Available online: https://www.hpfminerals.kr/images/uploads/Datenblaeter/Silica/1201-MILLISIL-SMF-HPF.pdf (accessed on 30 November 2020).

41. Wichern, M.; Pecher, H.; Helmreich, B. Untersuchungs- und Entwicklungsvorhaben im Bereich Abwasser zum Themenschwerpunkt Niederschlagswasserbeseitigung, Brief Report 2017. Available online: https://www.lanuv.nrw.de/fileadmin/tx_ mmkresearchprojects/Kurzbericht_Spurenstoffe_20170327.pdf (accessed on 30 November 2020).

42. SenStadtUm Senatsverwaltung für Umwelt, Verkehr und Klimaschutz (SenStadtUm): Verkehrslenkung Berlin-Straßenverkehrserhebung VLB C, Traffic Volume Map 2014. Available online: http://www.stadtentwicklung.berlin.de/verkehr/lenkung/vlb/de/ erhebungen.shtml; (accessed on 30 November 2020).

43. Sieker, F.; Grottker, M. Beschaffenheit von Straßenoberflächenwasser bei Mittler Verkehrsbelastung Forschung Straßenbau und Straßenverkehrstechnik; 530 Bundesminister für Verkehr, Abteilung Straßenbau: Bonn-Bad Godesberg, Germany, 1988.

44. Dehghani, S.; Moore, F.; Akhbarizadeh, R. Microplastic pollution in deposited urban dust, Tehran metropolis, Iran. Environ. Sci. Pollut. Res. 2017, 24, 20360-20371. [CrossRef]

45. Zheng, L.; Tang, Q.; Fan, J.; Huang, X.; Jiang, C.; Cheng, H. Distribution and health risk assessment of mercury in urban street dust from coal energy dominant Huainan City, China. Environ. Sci. Pollut. Res. 2015, 22, 9316-9322. [CrossRef]

46. Patinha, C.; Duraes, N.; De Sousa, P.L.; Dias, A.C.; Reis, A.P.; Noack, Y.; Da Silva, E.F. Assessment of the influence of traffic-related particles in urban dust using sequential selective extraction and oral bioaccessibility tests. Environ. Geochem. Health 2015, 37, 707-724. [CrossRef]

47. DIN 66165-1:2016-08, Partikelgrößenanalyse_- Siebanalyse_- Teil_1: Grundlagen / Particle size analysis-Sieving analysis-Part 1: Fundamentals. 2016. Available online: https://www.beuth.de/de/norm/din-66165-1/255316600 (accessed on 30 November 2020).

48. Vaze, J.; Chiew, F.H. Experimental study of pollutant accumulation on an urban road surface. Urban Water 2002, 4, 379-389. [CrossRef]

49. Egodawatta, P.; Goonetilleke, A. Understanding road surface pollutant wash-off and underlying physical processes using simulated rainfall. Water Sci. Technol. 2008, 57, 1241-1246. [CrossRef] 
50. Unice, K.; Weeber, M.; Abramson, M.; Reid, R.; van Gils, J.; Markus, A.; Vethaak, A.; Panko, J. Characterizing export of land-based microplastics to the estuary-Part I: Application of integrated geospatial microplastic transport models to assess tire and road wear particles in the Seine watershed. Sci. Total Environ. 2019, 646, 1639-1649. [CrossRef]

51. Hallberg, M. Treatment conditions for the removal of contaminants from road runoff. 2007 Stockholm: [Byggvetenskap, Kungliga Tekniska högskolan] (Trita-LWR. PHD, 1032). Available online: http://kth.diva-portal.org/smash/get/diva2:12086/FULLTEXT0 1 (accessed on 30 November 2020).

52. Leutnant, D.; Uhl, M. In-situ Monitoring großer dezentraler Behandlungsanlagen für Niederschlagsabflüsse. In 12. Rostocker Abwassertagung - Emissionsminderung von Punktquellen im ländlichen Raum; Tränckner, J., Ed.; FH Münster-University of Applied Sciences: Münster, Germany, 2019; pp. 79-85.

53. Andersson-Sköld, Y.; Johannesson, M.; Gustafsson, M.; Järlskog, I.; Lither, D.; Polukarova, M.; Strömvall, A.-M. Microplastics from Tyre and Road Wear: A Literature Review Swedish National Road and Transport Research Institute (VTI) 2020; VTI Rapport 1028A. Available online: http:/ /vti.diva-portal.org/smash/get/diva2:1430623/FULLTEXT02.pdf (accessed on 30 November 2020).

54. Behrendt, J.; Rechtenbach, D.; Otterpohl, R. Themenschwerpunkte: Mikroschadstoffe, Mikroplastik, Antibiotikaresistenzen, Industrieabwasserbehandlung, Niederschlagswasser, Umweltwärme, Klärschlammentsorgung, Gewässerschutz; (Hamburger Berichte zur Siedlungswasserwirtschaft, Band Nr. 100); 31. Hamburger Kolloquium zur Abwasserirtschaft: Hamburg, 18. und 19; GFEU: Hamburg, Germany, 2019.

55. DIN 38409-2:1987-03. German Standard Methods for the Examination of Water, Waste Water and Sludge; Parameters Characterizing Effects and Substances (group H); Determination of Filterable Matter and the Residue on Ignition (H 2). Available online: https: / / www.beuth.de/de/norm/din-38409-2/1340135 (accessed on 30 November 2020).

56. DIN 38402-11:2009. German Standard Methods for the Examination of Water, Waste Water and Sludge-General Information (group A)—Part 11: Sampling of waste water (A 11). Available online: https://www.beuth.de/de/norm/din-38402-11/1088559 69 (accessed on 30 November 2020).

57. ISO 11352. Water Quality - Estimation of Measurement Uncertainty Based on Validation and Quality Control Data (ISO 11352:2012). Available online: https:/ / www.beuth.de/de/norm/din-iso-11352/169811561 (accessed on 30 November 2020).

58. Bundesinstitut für Bau-, Stadt- und Raumforschung (BBSR). Überflutungs- und Hitzevorsorge durch die Stadtentwicklung. In Strategien und Maßnahmen zum Regenwassermanagement Gegen Urbane Sturzfluten und Überhitze Städte: Ergebnisbericht der Fallstudiengestützten Expertise "Klimaanpassungsstrategien zur Überflutungsvorsorge Verschiedener Siedlungstypen als Kommunale Gemeinschaftsaufgabe"; Bundesinstitut für Bau-, Stadt- und Raumforschung: Bonn, Germany, April 2015. 